\title{
THE
}

\section{The Significance of the South Atlantic Equatorial Countercurrent to the Ecology of the Green Turtle Breeding Population of Ascension Island}

C. W. Brown

University of Rhode Island

Follow this and additional works at: https://digitalcommons.uri.edu/gsofacpubs

Terms of Use

All rights reserved under copyright.

\section{Citation/Publisher Attribution}

Brown, C. (1990). The Significance of the South Atlantic Equatorial Countercurrent to the Ecology of the Green Turtle Breeding Population of Ascension Island. Journal of Herpetology, 24(1), 81-84. doi:10.2307/ 1564294

Available at: http://dx.doi.org/10.2307/1564294

This Article is brought to you for free and open access by the Graduate School of Oceanography at DigitalCommons@URI. It has been accepted for inclusion in Graduate School of Oceanography Faculty Publications by an authorized administrator of DigitalCommons@URI. For more information, please contact digitalcommons-group@uri.edu. 
The Significance of the South Atlantic Equatorial Countercurrent to the Ecology of the Green Turtle Breeding Population of Ascension Island

Author(s): C. W. Brown

Source: Journal of Herpetology, Vol. 24, No. 1 (Mar., 1990), pp. 81-84

Published by: Society for the Study of Amphibians and Reptiles

Stable URL: https://www.jstor.org/stable/1564294

Accessed: 27-11-2018 20:01 UTC

JSTOR is a not-for-profit service that helps scholars, researchers, and students discover, use, and build upon a wide range of content in a trusted digital archive. We use information technology and tools to increase productivity and facilitate new forms of scholarship. For more information about JSTOR, please contact support@jstor.org.

Your use of the JSTOR archive indicates your acceptance of the Terms \& Conditions of Use, available at https://about.jstor.org/terms

Society for the Study of Amphibians and Reptiles is collaborating with JSTOR to digitize, preserve and extend access to Journal of Herpetology 
AND D. M. SECOY. 1983. Demography, growth, and food of western painted turtles, Chrysemys picta bellii (Gray), from southern Saskatchewan. Canadian J. Zool. 61:1499-1509.

MCAuliffe, J. R. 1978. Seasonal migrational movements of a population of the western painted turtle, Chrysemys picta bellii (Reptilia, Testudines, Testudinidae). J. Herpetol. 12:143-149.

MosKoviTs, D.K. 1988. Sexual dimorphism and population estimates of the two Amazonian tortoises (Geochelone carbonaria and G. denticulata) in northwestern Brazil. Herpetologica 44:209-217.

Otis, D. L., K. P. Burnham, G. C. White, and D. R. ANDERSON. 1978. Statistical inference from capture data on closed animal populations. Wildl. Monogr. 62:1-135.

Plummer, M. V. 1977. Activity, habitat and population structure in the turtle, Trionyx muticus. Copeia 1977: 431-440.

REAM, C., AND R. REAM. 1966. The influence of sampling methods on the estimation of population structures in painted turtles. Amer. Midl. Nat. 75: 325-338.

RobSON, D. S., AND H. A. RegIER. 1968. Estimation of population number and mortality rates. In $\mathrm{W}$. E. Ricker (ed.), Methods for assessment of fish production in fresh waters, pp. 124-158. IHP Handbook No. 3, Blackwell Scientific Publ., Oxford.

SCHWARTZ, E. R., C. W. SChWARTZ, AND A. R. Kiester. 1984. The three-toed box turtle in central Missouri, Part II: a nineteen-year study of home range, movements and population. Missouri Dept. Cons., Terr. Ser. No. 12:1-28.

SEBER, G. A. F. 1965. A note on the multiple-recapture census. Biometrika 52:249-259.

1973. The estimation of animal abundance and related parameters. Griffin, London. $506 \mathrm{pp}$.

SEIGEL, R. A. 1984. Parameters of two populations of diamondback terrapins (Malaclemys terrapin) on the Atlantic coast of Florida. In R. A. Seigel, L. E. Hunt, J. L. Knight, L. Malaret, and N. L. Zuschlag (eds.), Vertebrate ecology and systematics: a tribute to Henry S. Fitch, pp.77-87. Univ. Kansas Mus. Nat. Hist., Lawrence.

WADE, S. E., AND C. E. GifFord. 1964. A preliminary study of the turtle population of a northern Indiana lake. Proc. Indiana Acad. Sci. 74:371-374.

WHITE, G. C. 1971. A FORTRAN listing for the stochastic model of G. M. Jolly. Tussock Grasslands and Mountain Lands Inst. Spec. Publ. 8. Lincoln College, Christchurch, New Zealand. 33 pp.

, D. R. ANDERson, K. P. BurnhaM, AND D. L. OTIS. 1982. Capture-recapture and removal methods for sampling closed populations. Report LA-8787-NERP, Los Alamos National Laboratory, Los Alamos, New Mexico. 235 pp.

WILBUR, H. M. 1975. The evolutionary and mathematical demography of the turtle Chrysemys picta. Ecology 56:64-77.

Williams, E. C., AND W. S. PARKer. 1987. A longterm study of a box turtle (Terrapene carolina) population at Allee Memorial Woods, Indiana, with emphasis on survivorship. Herpetologica 43:328335.

Accepted: 20 September 1988.
Journal of Herpetology, Vol. 24, No. 1, pp. 81-84, 1990

Copyright 1990 Society for the Study of Amphibians and Reptiles

\section{The Significance of the South Atlantic Equatorial Countercurrent to the Ecology of the Green Turtle Breeding Population of Ascension Island}

C. W. BRown, Graduate School of Oceanography, University of Rhode Island, Narragansett, Rhode Island 02882, USA.

The occurrence of long-distance migration of adult Atlantic green turtles, Chelonia mydas, from their Brazilian feeding grounds to their nesting beaches on Ascension Island is well documented (Carr and Hirth, 1962; Carr, 1975; Meylan, 1982; Mortimer and Carr, 1987). However, there are few data on the route taken and the environmental cue(s) used in the open-sea navigation to Ascension Island, a $96 \mathrm{~km}^{2}$ island positioned $2300 \mathrm{~km}$ east of the easternmost bulge of Brazil at $14^{\circ} 20^{\prime} \mathrm{W}, 7^{\circ} 57^{\prime} \mathrm{S}$.

Carr and others (Carr, 1962, 1972; Koch et al., 1969; Carr and Coleman, 1974) have suggested that a dual sun-compass/chemosensory mechanism is involved in navigation. As proposed, turtles would depart from the feeding grounds, initially swimming in a genetically established direction and later heading in the direction of the rising sun. They would continue to use the sun to obtain daily headings until intersecting a plume of chemical substance(s) emanating from Ascension Island. This chemosensory cue, unique to Ascension Island, would be carried in the surface mixed layer of the westward flowing South Atlantic Equatorial Current (SEC). By swimming upstream against the SEC and in the direction of highest substance concentration, the turtles would eventually reach Ascension Island. The westward SEC would also provide a vehicle for the trip of the passively drifting hatchlings into their next developmental habitat-either on the South American coastal feeding pastures (Carr and Hirth, 1962) or into a pelagic environment.

At the time the above navigation mechanism was proposed, the structure and seasonal variability of the SEC and other currents within the equatorial region were not well known, and were replete with distortions (Reid, 1964a). This note reviews recent physical oceanographic literature indicating that Ascension Island is located in the middle of an eastward current, and discusses the ecological implications of the presence of this countercurrent upon the migration and the dispersal of C. mydas to and from the island.

The Atlantic current system immediately south of the equator may be represented as branches of the westward flowing SEC separated by two distinct bands of eastward flowing currents-the South Equatorial Undercurrent (SEUC), located between $3^{\circ}$ and $5^{\circ} \mathrm{S}$, and the South Equatorial Countercurrent (SECC), located typically between $7^{\circ}$ and $9^{\circ} \mathrm{S}$ (Fig. 1) (Molinari et al., 1981; Molinari, 1982). Only the SECC will be described because of its latitudinal position and impingement on Ascension Island.

The SECC is an eastward flowing current at depth with a westward or eastward surface flow dependent 


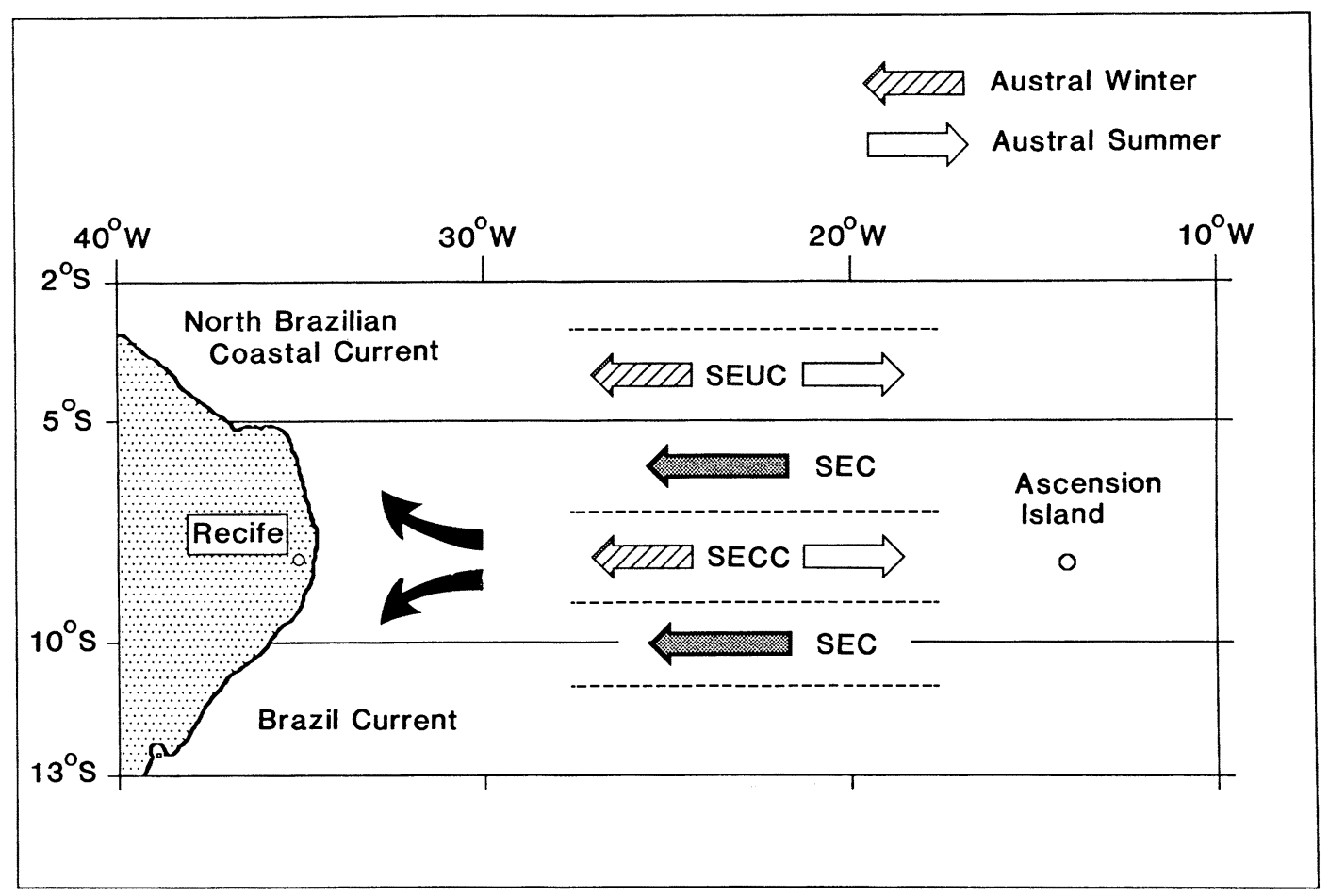

FIG. 1. Schematic representation of surface current flow of the South Equatorial Current (SEC), the South Equatorial Undercurrent (SEUC), and the South Equatorial Countercurrent (SECC) off the coast of Brazil. Seasonal surface flow in the SECC is indicated. Dashed lines represent degrees of latitude. The surface divergence located at $8^{\circ} \mathrm{S}$ is also illustrated.

on the magnitude of the southeast trade winds. Eastward flow was detected between $7^{\circ}$ and $9^{\circ} \mathrm{S}$ in both the austral summer and winter (Reid, 1964a, $b$; Molinari, 1982) to the west of Ascension Island using a standard oceanographic method (=geostrophic flow approximation; see Pond and Pickard, 1978). Eastward surface flow is more extensive during austral summer. Flow during July at $14^{\circ} \mathrm{W}$, the longitude of Ascension Island, was eastward with speeds of 0.04 to $0.07 \mathrm{~m} / \mathrm{sec}$ (Reid, 1964a). Maximum eastward speeds of approximately $0.10 \mathrm{~m} / \mathrm{sec}$ were calculated at a depth of 275 $\mathrm{m}$.

In contrast to these geostrophic flow calculations, Molinari (1983a) and Reverdin and McPhaden (1986) noted that the mean trajectory of drifting surface buoys was to the west between $7^{\circ}$ and $11^{\circ} \mathrm{S}$ and $23^{\circ}$ and $31^{\circ} \mathrm{W}$ during austral winter. Eastward drift within the SECC was observed though for a four month period during austral summer (Molinari, 1983a). The observed discrepancy between the geostrophic and buoy data may be attributable to direct forcing of the surface layer by the wind.

Molinari (1983a) proposed that the strong southeast trade winds during winter can induce directly driven surface flows to the west that are more intense than the eastward geostrophic flows associated with the SECC (Molinari, 1983a). The upper ocean equatorial circulation has a pronounced annual cycle which is almost in phase with the annual changes in the surface winds (Katz, 1981; Molinari, 1983b; Weisberg, 1985; Hisard et al., 1986). In the region of the SECC there is a seasonal cycle in the intensity of southeast trades with highest wind speeds $(6-8 \mathrm{~m} / \mathrm{sec})$ occurring during austral winter and lowest wind speeds (4-6 m/sec) occurring during summer (Hastenrath and Lamb, 1977). Average surface wind drift current speeds of 0.08 to $0.11 \mathrm{~m} / \mathrm{sec}$ and 0.05 to $0.08 \mathrm{~m} / \mathrm{sec}$, respectively, were calculated from these climatological data (Molinari, 1983a). The direction of these windinduced currents are to the west in the southern hemisphere (Pond and Pickard, 1978).

A surface divergence at $8^{\circ} \mathrm{S}$ near $31^{\circ} \mathrm{W}$ (Fig. 1) was also apparent by the trajectories of the surface buoys (Molinari, 1983a). Buoys deployed north of $8^{\circ} \mathrm{S}$ showed a mean northward meridional component and entered into the North Brazilian Coastal Current. Buoys released south of $8^{\circ} \mathrm{S}$ showed a southward meridional component and drifted southward into the Brazil Current. Reverdin and McPhaden (1986) did not witness the entrainment of buoys into the Brazil Current.

The presence of the eastward flowing SECC has several implications to the ecology of the Ascension Island green turtle breeding population. The consequence of the SECC upon hatchlings must be viewed in context of the seasonal surface flow. The main nesting period of C. mydas on Ascension Island occurs between late February and April, though the complete nesting season extends from December to June (Carr and Hirth, 1962; Mortimer and Carr, 1987). The average incubation period for Ascension C. mydas eggs is approximately 60 days (Carr and Hirth, 1962). With respect to the peak nesting period, the greatest num- 
ber of hatchlings emerge from the nests between late April and June. Hatchlings departing from Ascension Island prior to the intensification of the southeast trade winds in May could experience an eastward surface drift. Because nesting begins in January, the probability of the earliest emerging hatchlings being transported toward Africa is higher than those hatching after the intensification. Interannual variability of the onset of the southeast trades would lead to a variation in the percentage of hatchlings involved in the eastward dispersal pattern. The date of onset of the trade winds near the equator varies interannually over a range of approximately one month (Garzoli and Katz, 1984). The greater the delay of the intensification, the more hatchlings will be affected. Due to the lack of knowledge of both the SECC to the east of Ascension Island and hatchling behavior during dispersal, the effect of the eastward dispersal pattern on hatchling survival cannot be assessed.

After the intensification of the trade winds, the surface layer would flow consistently westward. The positively buoyant hatchlings, assuming no active swimming, would remain in the surface layer of the SECC and be transported westward for the open-sea portion of the trip towards Brazil. This would include the majority of hatchlings. The length of time required for a hatchling to drift with westward surface currents with an average speed of $0.08 \mathrm{~m} / \mathrm{sec}$ from Ascension Island to $31^{\circ} \mathrm{W}$, the longitude at which buoys deviate from a straight path (Molinari, 1983a), is approximately 9 months. The same route would be taken by adults, but with the capacity for active swimming, they could arrive at their destination considerably faster. The surface divergence noted by Molinari $(1983 a)$ would also influence whether the turtles move to regions to the north or south of the Brazilian bulge. If juvenile turtles occupy a pelagic developmental stage, as Carr (1986) suggests, the consequence of this surface divergence would be to place turtles into either the North or the South Atlantic Ocean-two potentially different oceanic habitats.

On the migratory trip of adults from the Brazilian coast, the SECC provides a conduit towards Ascension Island. The turtles need only remain within its borders. The swimming efforts of the turtle would be augmented by the current, decreasing the energetic cost of travel to the migrating turtle. This is an adaptive feature, especially for nesting females, as compared to the upstream swim required in the scenario described earlier. The time required to traverse the $2300 \mathrm{~km}$ distance would range from 51 to 57 days, calculated from the sum of normal swimming speeds recorded for green turtles during internesting intervals at Ascension $(1.5 \mathrm{~km} / \mathrm{h}=0.42 \mathrm{~m} / \mathrm{sec}$ ) (Carr et al., 1974) and of eastward geostrophic speeds reported for the depth of maximum speed $(0.10 \mathrm{~m} / \mathrm{sec})$ and the surface layer $(0.05 \mathrm{~m} / \mathrm{sec})$ (Molinari, 1982), respectively.

The use of the chemosensory component of the navigation mechanism during open-sea migration is doubtful given the existence of the SECC. A sensory plume from Ascension Island would extend downstream towards Africa, not Brazil, during the seasonal migration. The transport of substance towards Brazil by wind-driven surface currents is possible, but probably insignificant during this period. The wind intensity is weak during austral summer and only the top-most layer is directed westward (Pond and Pickard, 1978). Alternatively, the interannual meridional variability of the SECC could allow the westward flowing SEC to intermittently intersect and transport substances from Ascension to Brazil. But relying upon a navigational system based on a sensory cue which is variable in time and space seems highly improbable.

The existence of the SECC dictates changes in the present navigation-migration model. The SECC prevents the formation of a discernible chemical trail by which the adult turtles could navigate to Ascension Island. The compass sense still remains a viable component of the proposed navigational mechanism to determine latitude, but another sensory cue is necessary to provide the longitudinal information. The SECC also decreases the energetic expense of the longdistance migration by augmenting the swimming efforts of the turtles in the general direction of Ascension Island. The westward direction of the surface drift currents allows these proposed alterations in the navigation-migration model, while retaining the physical mechanism to transport the majority of hatchlings towards the coast of Brazil and into their next developmental habitat.

Acknowledgments. - I thank R. L. Molinari for informing me of several recent papers pertaining to the physical oceanography in the equatorial South Atlantic, and C. R. Shoop, N. Garfield III and two anonymous reviewers for improving the manuscript. S. Graves kindly assisted in the preparation of Fig. 1.

\section{LiteRATURE CITED}

CARR, A. 1962. Orientation problems in the high sea travel and terrestrial movements of marine turtles. Amer. Sci. 50:359-372.

- 1972. The case for long-range chemoreceptive piloting in Chelonia. In S. R. Galler, K. SchmidtKoenig, G. J. Jacobs, and R. E. Belleville (eds.), Animal orientation and navigation, pp. 469-483. Sci. Techn. Inform. Off. NASA, Washington, D.C. 1975. The Ascension Island green turtle colony. Copeia 1975(3):547-555.

- 1986. New perspectives on the pelagic stage of sea turtle development. U.S. Department of Commerce, N.O.A.A. Techn. Memo., NMFS-SEFC190. Panama City, Florida. 36 pp.

, AND P. J. COLEMAN. 1974. Seafloor spreading theory and the odyssey of the green turtle. Nature 249:128-136.

$\longrightarrow$, AND H. HIRTH. 1962. The ecology and migrations of sea turtles, 5. Comparative features of isolated green turtle colonies. Amer. Mus. Nov. 2091:1-42.

- P. Ross, AND S. CARR. 1974. Internesting behavior of the green turtle, Chelonia mydas, at a mid-ocean island breeding ground. Copeia 1974(3): 703-706.

Garzoli, S. L., AND E. J. Katz. 1984. Winds at St. Peter and St. Paul Rocks during the first SEQUAL year. Geophys. Res. Lett. 11(8):715-718.

Hastenrath, S., AND P. Lamb. 1977. Climatic atlas of the Tropical Atlantic and Eastern Pacific Oceans. Univ. Wisconsin Press, Madison. 112 pp.

Hisard, P., C. Henin, R. Houghton, B. Piton, and P. RAUL. 1986. Oceanic conditions in the tropical 
Atlantic during 1983 and 1984. Nature 332:243245.

KATZ, E. J. 1981. Dynamic topography of the seasurface in the equatorial Atlantic. J. Mar. Res. 39: 53-63.

KocH, A. L., A. CARR, AND D. W. Ehrenfeld. 1969. The problem of open-sea navigation: the migration of the green turtle to Ascension Island. J. Theoret. Biol. 22:163-179.

MEYLAN, A. B. 1982. Sea turtle migration-evidence from tag returns. In K. A. Bjorndal (ed.), Biology and conservation of sea turtles, pp. 91-102. Smithsonian Instit. Press, Washington, D.C.

MOLINARI, R. L. 1982. Observations of eastward currents in the tropical South Atlantic Ocean: 19781980. J. Geophys. Res. 87(C12):9707-9714.

1983a. Observations of near-surface currents and temperature in the central and western tropical Atlantic Ocean. J. Geophys. Res. 88(C7):44334438.

- $1983 b$. Sea-surface temperature and dynamic height distributions in the central tropical South Atlantic Ocean. Oceanol. Acta 6(1):29-34.

- B. VORTURIEZ, AND P. DUNCAN. 1981. Observations in the subthermocline undercurrent of the Equatorial South Atlantic Ocean: 1978-1980. Oceanol. Acta 4(4):451-456.

MORTIMER, J. A., AND A. CARR. 1987. Reproduction and migration of the Ascension Island green turtles (Chelonia mydas). Copeia 1987(1):103-113.

POND, S., AND G. L. PICKARD. 1978. Introductory dynamic oceanography. Pergamon Press, Inc., Elmsford, New York. 241 pp.

REID, J. L., JR. 1964a. A transequatorial Atlantic oceanographic section in July 1963 compared with other Atlantic and Pacific sections. J. Geophys. Res. 69(24):5202-5215.

-1964b. Evidence of a South Equatorial Countercurrent in the Atlantic Ocean in July 1963. Nature 203:182.

REVERDIN, G., AND M. J. MCPhADEN. 1986. Near-surface current and temperature variability observed in the equatorial Atlantic from drifting buoys. J. Geophys. Res. 91(C5):6569-6581.

WEISBERG, R. H. 1985. Equatorial Atlantic velocity and temperature observations: February-November 1981. J. Phys. Oceanogr. 15(5):533-543.

Accepted: 4 November 1988.

Journal of Herpetology, Vol. 24, No. 1, pp. 84-87, 1990 Copyright 1990 Society for the Study of Amphibians and Reptiles

\section{Scaling of the Epicoracoid Horn Muscle in Arciferal Frogs}

SHARON B. EMERSON, Department of Biology, University of Utah, Salt Lake City, Utah 84112, USA.

Frogs show a striking dimorphism in the morphology of the pectoral girdle (Griffiths, 1963; Trueb, 1973), and this difference has been a major character in anuran systematics for over a century (Cope, 1865).
In some species the epicoracoid cartilages are fused at the ventral midline, and the right and left sides of the girdle are fixed. In other species the cartilages are free and overlapping along the midline and the two halves of the girdle can move independently. Biomechanical analyses (Emerson, 1983, 1984) have shown that the two types of girdles have similar biological roles but function quite differently. While the fused, firmisternal girdle resists the impact forces of jump landing through compression, the unfused, arciferal girdle is loaded both in tension and compression. This note extends that earlier work by examining the specific biological role of a small muscle that contributes to the observed functional differences between girdle types.

Frog arciferal girdles are characterized by overlapping ventral cartilages which terminate posteriorly in tendinous attachments to ascending slips of the parallel fibered rectus abdominis muscle Bigalke, 1927, Fig. 5; Bhati, 1955, Fig. 18; Emerson, 1984, Fig. 1). The rectus abdominis muscle originates from the inferior border of the pubes and runs anteriorly as the major, ventral body wall muscle (Gaupp, 1896). The lateral portion of the muscle becomes confluent with the abdominal section of the pectoralis muscle and inserts on the humerus. The major portion of the medial muscle mass of the rectus abdominis continues forward along the midline to become the sternohyoideus, inserting on the hyoid plate. It is a small slip of this inner portion that differentiates and attaches to the epicoracoid cartilages in arciferal frogs.

The tendinous attachments of these slips of the rectus abdominis were named 'epicoracoid horns' by Griffiths (1963), and their presence has been used as a diagnostic feature of arcifery. The precise biological role of the muscles attached to the epicoracoid horns (=epicoracoid horn muscle) remains unknown, but their function has been established. Contraction of the epicoracoid horn muscle stabilizes the epicoracoid cartilages at the midline and stiffens the arciferal girdle, limiting deformation (Emerson, 1983).

The object of this note is to report results of a study that used allometry to explore further the potential contribution of the epicoracoid horn muscle in reducing the force of landing through indirect involvement in energy absorption during impact loading (Emerson, 1984)

The force of a parallel-fibered muscle is proportional to its cross-sectional area (Alexander, 1968). If geometric similarity is maintained with increasing body size, muscle area should scale to body weight with a slope of 0.67 (and to body length with a slope of 2.0). With geometric similarity, relative muscle force (or function) decreases with increases in size. Studies of frog hindlimb musculature have confirmed this geometric scaling relationship in at least some species (van der Stelt and Klijn, 1975; Emerson, 1978; Sperry, 1981). Therefore, geometric similarity is considered to be a realistic null hypothesis for the relationship between muscle cross-sectional area and body size in this study.

The conservation of momentum equation (White, 1962) shows that

$$
\mathrm{F} \times \mathrm{T}=\mathrm{M}_{1} \mathrm{~V}_{1}-\mathrm{M}_{0} \mathrm{~V}_{0}
$$

where $\mathrm{F}=$ force, $\mathrm{T}=$ time, $\mathrm{F} \times \mathrm{T}$ is the impulse, and $M_{1} V_{1}-M_{0} V_{0}$ is the change in momentum. The final 